\title{
Evolution of Land Use in Two Drainage Basins in an Urban Area of Brasília-DF/Brazil
}

\author{
Gabriella Emilly Pessoa, Valdir Adilson Steinke \\ Department at Geography, University of Brasília, Brasília, Brazil \\ Email: gabriellaemilly@gmail.com, valdirs@unb.br
}

How to cite this paper: Pessoa, G. E., \& Steinke, V. A. (2020). Evolution of Land Use in Two Drainage Basins in an Urban Area of Brasília-DF/Brazil. Journal of Service Science and Management, 13, 769-784. https://doi.org/10.4236/jssm.2020.136048

Received: September 17, 2020

Accepted: November 16, 2020

Published: November 19, 2020

Copyright $\odot 2020$ by author(s) and Scientific Research Publishing Inc. This work is licensed under the Creative Commons Attribution International License (CC BY 4.0).

http://creativecommons.org/licenses/by/4.0/

\begin{abstract}
The city of Brasilia, Brazil, is internationally known for its modern architecture based on the urbanism project of Lúcio Costa, which contemplated the urban center. Nowadays, despite partial planning and being one of the most famous urban landscapes in the world, the city presents frequent and challenging problems, among which we can highlight the countless cases of floods in various sectors of the urban area. This research had the objective to analyze the processes of use and occupation of the land in two drainage basins of first-order located in different urban nuclei full of paradoxes. Two drainage basins were selected, one located in Asa Norte, that is, inserted in the original planning of Lucio Costa, and another located in a region of recent urban expansion called Aguas Claras. For both basins, the analysis of land use was carried out in two distinct periods, 1964 and 2019. The results indicate that the city advanced exponentially over the original vegetation areas, with changes above $500 \%$ of the replacement of savannah by urban area. It should also be noted that the mere architectural planning of the city did not take into account the essential characteristics of the territory, since basic elements, such as topography and relief, that provide extremely relevant subsidies for drainage systems, were relegated.
\end{abstract}

\section{Keywords}

Urban Drainage Basin Modeling, Water Flow, Water Accumulation Spots, Superficial Urban Planning, Water Drainage Grid

\section{Introduction}

In a synthetic but comprehensive way, it is possible to define urbanization as the transformation of a determined portion of the land surface into a high-density city. It is a process that has been developing for more than 5000 years. According 
to Braga \& Carvalho (2004), the first cities appeared in Mesopotamia, then in North Africa (Nile Valley), and it spread through Asia. Cities expanded across the Mediterranean and Europe, under the Greek and Roman civilizations.

In America, cities developed in Central America more than 2000 years ago, under the Mayan and Aztec civilizations. In the 19th century, urbanization accelerated vigorously after the Industrial Revolution, when the structure of cities was characterized by a spatial arrangement suitable to the capitalist-industrial mode of production. Since then, the urbanization process has continued at an accelerated pace to the point that, in 2007, the world's urban population surpassed the world's rural population quantitatively.

Cities can be seen as the culmination of the spatial organization by societies. In this line of thought, Braga \& Carvalho (2004) point out that the city can be understood as the most radical intervention of society in the landscape. It can be understood as the synthesis of civilization, whose way of life permeates not only its structure but its entire region of influence, shaping an urban world beyond its borders. The growth of cities, which occurs generally in a disorderly manner, becomes a universal problem due to the uneven distribution of infrastructure and basic services over urban space, which continues to be unevenly distributed among the population.

To think and to build the urban space, urban planning must happen at a local level. Urban planning is one of the most important activities in structuring spatial arrangements and urban networks. It optimizes citizens' access to services and functions that the urban structure must perform, in the context of a larger, more comprehensive geographic network.

One of the greatest challenges for big urban cities and, especially, modern cities, is the proper planning of their territory. The cities built in the 20th century should be revisited to be planned against the flooding problems triggered by the models of urban expansion. However, public managers reportedly ignore the mistakes made and continue to use models that are known to not work, since the flooding still happens every year.

Both hydrographic and drainage basins can be defined as the surface area that contributes to a specific channel or a set of channels. Therefore, it is a land area in which rainfall and/or snowmelt channels into streams, rivers until it reaches an outflow point, such as reservoirs, bays, and, of course, the ocean itself. It is also described as an area of land that contains a set of streams that drains to a larger body of water. It constitutes an important unit of the water balance for the analysis of hydropedomorphogenic conditions with its dynamics, which complexity increases with the insertion of the different forms of use and management of soils that mold distinct landscapes in all regions (Leopold et. al., 1964; U.S. National Ocean Service (NOAA) (2020); U.S. Forest Service, 2019; Missouri Botanical Garden, 2002; U.S. Geological Survey (n.d.); Dunne \& Leopold, 1978; Steiner et al., 2000; Dietrich \& Dunne, 1993; Rhoades et al., 2011).

A wide and varied line of studies about drainage basins in urban areas has been carried out in different places of the world and with a wide range of me- 
thods. These urban basins are increasingly affected by anthropic uses and disorderly occupations, which caused problems for local populations in countless cities (Nelson, 1999; Abrams \& Prescott, 1999; Kennedy, 1999; Williams, 1999; Wardah et al., 2008; Papa et al., 2007; Adler, 2010; Garcia-Pintado et al., 2015; Sayama et al., 2015; Mishra et al., 2017; Hu, et al., 2017; Risi et al., 2013).

The city of Brasília, chosen to be the new capital of Brazil, is constructed based on an architectural transformation movement, which coincidentally was happening in the middle of the 20th century. With a promise to serve as a model for the world, with geometric marks of modernism and with the concern for sustainable development, the city began to be built in 1956. The new capital was a result of a campaign promise that was made by former Brazilian President Juscelino Kubitschek. The city was planned based on Lucio Costa's proposal, while most buildings were designed by Oscar Niemeyer. The new capital was inaugurated in 1960 and the city center, the Pilot Plan of Brasília, has become one of the greatest symbols of modern architecture of the world and one of UNESCO's world heritage sites. Due to restricted laws of the zoning ordinance in Brasilia and the lack of affordable housing in the capital, poor people are submitted to socio-spatial segregation (Deckker, 2016; Thornton, 2005).

The lack of planning the territory of the Federal District led to serious environmental problems and the existence of vacant areas. Not only for poor people who had to live in the outskirts of the new capital but for rich people who intended to live in the suburbs. First of all, the FD has a high-density population (22 inhabitants per $\mathrm{km}^{2}$ ) and, without proper urban planning, it results in environmental degradation. The pressure exercised by the population growth of Brasilia, numerous administrative regions were born without concern for public space or transportation. Hydrographic resources are seriously threatened mostly small and medium streams. Erosion also is one of the greatest problems in the Savannah area, since it is caused by mechanized agriculture, road constructions, deforestation, drainage systems, etc. This fragmented urban planning which did not consider the geomorphology of Brasilia affects those who live in the city today (Francisco et al., 2006; Deckker, 2016; Thornton, 2005; Tenorio \& Santos Jr., 2010; Salles et al., 2008).

Águas Claras is one of the most recent administrative regions (ARs) in the Federal District, inaugurated in 2003 to make feasible the subway construction in Brasília. The city is located around 13 miles from the Pilot Plan and has one of the greatest incomes of the District. To attend the population's leisure, there is the Ecological Park of Aguas Claras. The park has a lot of endemic species of the Savannah, with some exotic species introduced by former landowners. Due to the groundwater that emerges within the park, it is a very sensitive area (Cosac \& Silvano, 2016; Environmental Institute of Brasilia, 2017; Regional Administration of Águas Claras, 2020).

The Pilot Plan of Brasilia is divided into three sectors: Eixo Monumental, Asa Sul, and Asa Norte. Every summer, this UNESCO-listed World Heritage Site 
suffers from floods. Our study is focused on Asa Norte and Águas Claras, more specifically, on the Olhos d'Água and Córrego Águas Claras drainage basins. In this study, it is necessary to define the drainage basin as the streamflow from rainwater during the wet season, being the area where the precipitation starts to be collected. Those stream flows are not considered when planning cities, specially Brasília and Águas Claras, generating floods every summer in this UNESCO-listed World Heritage Site.

Studying drainage basins helps to understand the dynamics and the process of the floods that happens continuously every year in both cities. The modeling here proposed can be useful for future planning and it was never done before in Brasília. Also, the proposal of differentiating drainage basins from watersheds can be a useful tool for future urban planning. It is understood that there is no clear difference between a watershed and a drainage basin. Therefore, this work identifies a major problem when there is no difference between those concepts: when planning Brasília and later, Águas Claras, its urban planners did not look at the drainage system of the city, they did not look at the topography, geomorphology, hydrology: basic aspects of the territory. Proof of that is the frequent floods that happen in Asa Norte and Águas Claras.

Most plans of urbanization in watersheds do not consider its effects on hydrologic processes and intervention made by planners to mitigate flood has been minimal. Land-use planning must consider how a watershed works, taking into consideration its hydrological regime, riverine resources, and how it is affected by the land-use modification. The development of urban cities in watersheds increases the potential of flooding since it alters the hydrological processes such as infiltration, groundwater recharge, baseflow, and runoff. Deforestation and paving are some of the actions that can produce tremendous consequences in the delivery of water and sediment into the channel network, principally when it happens on the uplands. It also modifies hydrologic processes by grading land surface and constructing buildings and roads, since impervious surfaces in watersheds frequently result in increased surface runoff.

Urbanization changes the watershed throughout the years, tending to produce continuous changes in the downstream. The annual rate of channel change is influenced by abundant rainfall, easily erodible substrate, and the presence (or absence) of watershed urbanization, although not all channels respond in the same way and channel changes can vary according to the amount of rainfall (Booth \& Hershaw, 2001; Konrad \& Booth, 2002; Lin et al., 2007; Rogers \& DeFee, 2005; White \& Greer, 2006).

Urban sprawl in watersheds alters the way it functions, especially when it comes to the flow of water. Therefore, decisions made by landscape architects and urban planners influence the way the watershed functions over long periods. In developed watersheds, rainwater reaches the outflow point more quickly, which increases the chances of floods and less water is retained by the soils, increasing the potential for drought since the infiltration capacity becomes zero or 
next to this number. Impermeabilization affects directly the baseflow, which sustains streamflow during the dry seasons. Knowing how the runoff is generated allows us to recognize parts of the landscape that are likely to be major contributors of either storm runoff or groundwater recharge: precautions may have to be taken to avoid these zones or to detain water generated upon them (Dunne \& Leopold, 1996; Rogers \& DeFee, 2005).

Urban development within a catchment changes the land use drastically and it has major consequences on the functioning of the hydrological cycle during flood conditions. Stream degradation occurs at low levels of imperviousness, around $10 \%$. Beyond this $10 \%$, urban streams become unstable and it starts to erode its channels. When large areas get impervious, the hydrological cycle is affected by the fact that the area where precipitation can infiltrate is reduced and, consequently, overland flow can take place on the impermeable surface. It is important to freeze that type and degree of urbanization vary between catchments because of lithology, climate, geomorphology, topography, geology, etc. The vegetation removal can lower the infiltration capacity enough to generate large amounts of storm runoff where the previous runoff process was a slow subsurface process, occasioning saturated zones that provide floods (Dunne \& Leopold, 1996; Hollis, 1975; Schueler, 2000).

\section{Methodological Procedures}

The methodological procedures are articulated via spatial analysis in a geographic information system (GIS), in which the elements of the territory are overlapping in different temporality. Thus, it allows an analysis of the effects of land-use changes in a given period. Figure 1 shows a flowchart of the research steps.

The selected study areas are two drainage basins of first-order channels on a cartographic scale of 1:10,000, according to the classification of Strahler (1952). Being: 1) the Olhos D' Agua drainage basin, located in the North Wing of the Administrative Region of Brasília, also known as the Pilot Plan of Brasilia; and 2) the Aguas Claras drainage basin, located in the Administrative Region of Aguas Claras. Both drainage basins are first-order tributaries of the Lago Paranoá hydrographic basin, which means that they are sources for one of the most important hydrographic basins of the Federal District (Figure 2).

Geologically, they are based on the lithological group called Paranoá, which is the most relevant geological group in the territory of the FD. The predominant reliefs of the drainage basins were classified as Superior Planing, with less than $3 \%$ of the declivity. The original soils are already highly altered due to the anthropic activities triggered by the urbanization process and mechanized agriculture (Campos, 2004; Gonçalves et al., 2015; Salles et al., 2008; Steinke \& Sano, 2011).

To achieve the proposed objectives, data from the territory were gathered, such as geology, topography, relief, drainage, and original vegetation. In the second stage, data from aerial images were cut for two periods, 1964 and 2019, 
then classified according to land-use each year. All information was made available in the GIS environment, using ArcGIS Pro software. Crossing-data was performed, then it was made area value calculations for each land-use class, as well as the spatial distribution analysis in each drainage basin.

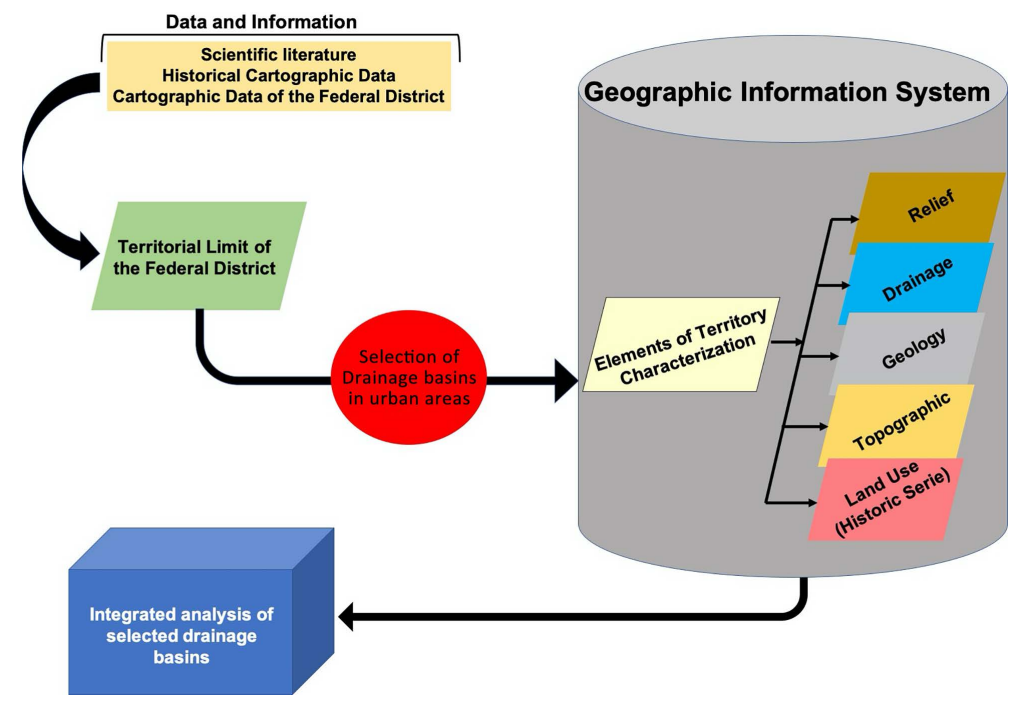

Figure 1. Flowchart of the research steps.
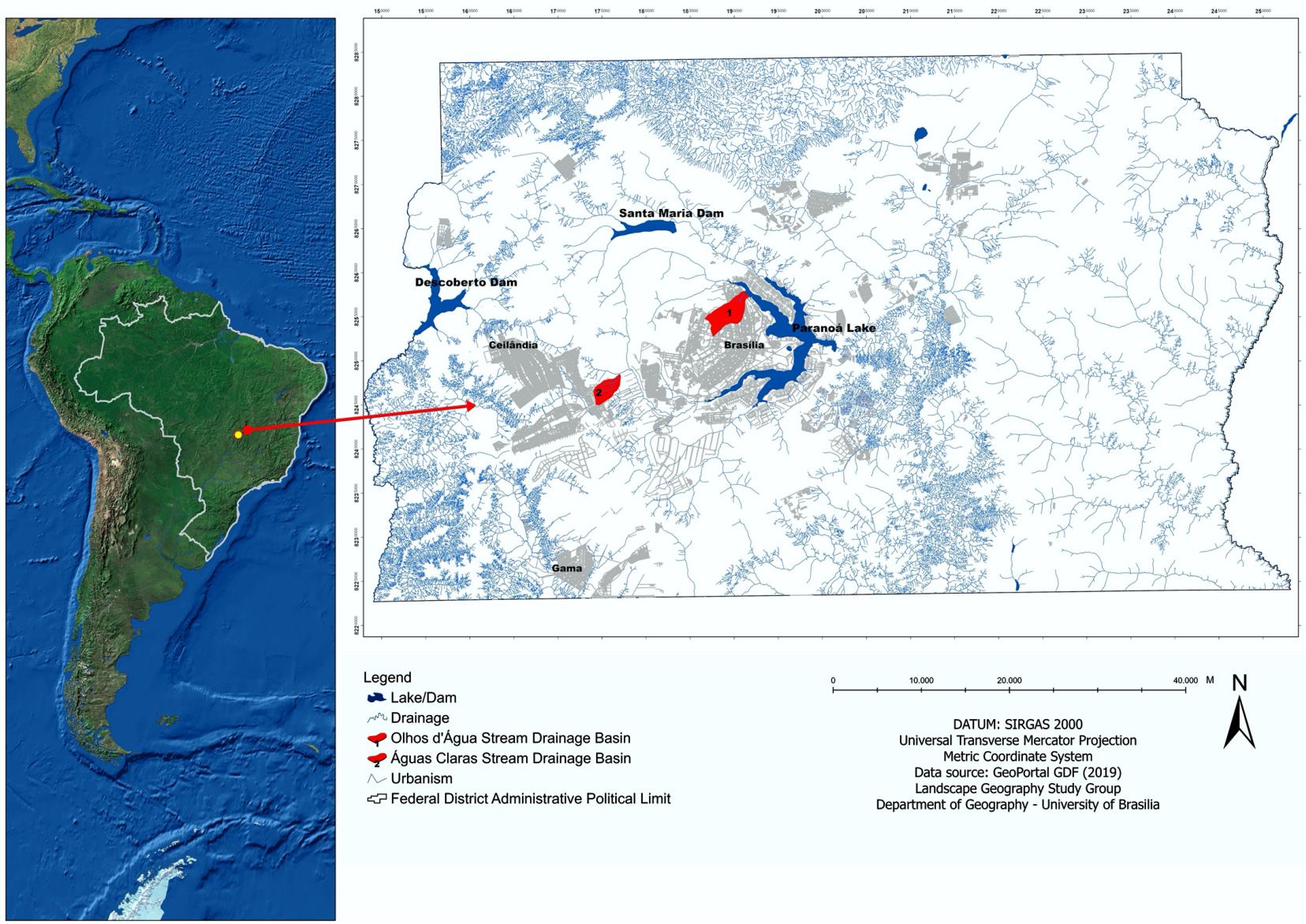

Legend

Lake/Dam

Drainage

Olhos d'Água Stream Drainage Basin

Águas Claras Stream Drainage Basin

Urbanism

F Federal District Administrative Political Limit

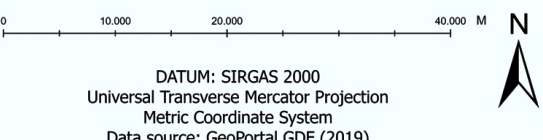

Data source: GeoPortal GDF (2019)

Landscape Geography Study Group

Department of Geography - University of Brasilia

Figure 2. Location of the study areas. 
The overlapping procedures were adjusted on a cartographic scale of 1:10,000, according to the existing information and spatial compatibility. Even with the availability of data in more detailed scales, such as the topography with data available on a scale of up to 1:2000. Even so, it was decided to work on a slightly smaller scale to avoid distractions of information and consequently mistakes in the results.

\section{Results and Discussion}

The results are presented in a specific way for the major problems caused by the change in land-use that occurred in the two drainage basins studied. These results follow the trend presented in studies of urban expansion in the Federal District of Brazil, such as those by Melo \& Steinke (2013) and Anjos et al. (2015), which points out to an accelerated growth axis in the southwest region of the territory of the FD.

\subsection{Drainage Basin of Olhos D’Água}

The terrain maps, especially the topographic maps, proved to be special. Since the channels are first-order tributary drainage basins according to the Strahler classification, usually they are intermittent or ephemeral channels. In situations of great anthropic pressure, with high population density rates, these channels tend not to support the runoff volume due to the topography.

This drainage basin system was totally transformed into an urban space. This drainage basin has a peculiar geomorphological characteristic since the drainage contribution area for the main channel represents more than $90 \%$ of the drainage basin. Originally, there was no stream present along the bottom of the drainage valley, which led to the interpretation that it was an area with little water activity, especially with little runoff.

However, it is verified that the geomorphological conformation of the drainage basin, with a large area of water catchment, has led to numerous urban drainage problems, such as numerous flood spots and inundation. This aspect is very evident in Figure 3, in which the comparison between the types of land-use between 1964 and 2019 are very explicit. The transformation that took place between classes of land-use, especially by replacing the original vegetation and the insertion of urban elements, is measured in Table 1.

From the previous table, the process of loss of savannah vegetation stands out, with a reduction of more than $70 \%$. Although the area called "areas with countryside vegetation" has emerged, they are recurrent processes of replacement of original vegetation by "urban voids" of very low biological quality. Naturally, channels from both drainage basins flow into Paranoá Lake.

However, due to the construction of roads that connect one superblock residential area to another, the Residential Road Axis, popularly called "little axis", the countless buildings in the region, and not having enough green spaces in this modern city, the precipitation cannot percolate through the numerous paved 
areas. Besides, the rainwater drainage system is ineffective in its objectives, causing flooding in many blocks of Asa Norte. Accumulation spots occur mainly in these "little axis", as they are one of the lowest and poorly dimensioned points of Brasilia, which happens to be located in the natural path of surface waters before reaching Lake Paranoá, forming areas of retention of runoff and causing flooding. A great example is the "little axis" that connects the residential areas called North Superblock of 109/110 and North Superblock 209/210, which is flooded very easily and frequently.

Table 1. Land-use evolution of the drainage basin Olhos d água.

\begin{tabular}{ccccccc}
\hline & \multicolumn{6}{c}{1964} \\
& Area (ha) & Area (\%) & Area (ha) & Area (\%) & Reduction (ha) & Increase (ha) \\
\cline { 2 - 7 } & 0.45 & 0.43 & 34.6 & 32.80 & - & 34.15 \\
Field & 84.2 & 79.81 & 11.5 & 10.90 & 72.7 & - \\
Savannah & 8.7 & 8.25 & 51.1 & 48.44 & - & 42.40 \\
Constructed area & 12.15 & 11.51 & 8.3 & 7.87 & 3.85 & - \\
Exposed soil & 105.5 & - & 105.5 & - & - & - \\
Total Area (ha) & 10.5 &
\end{tabular}
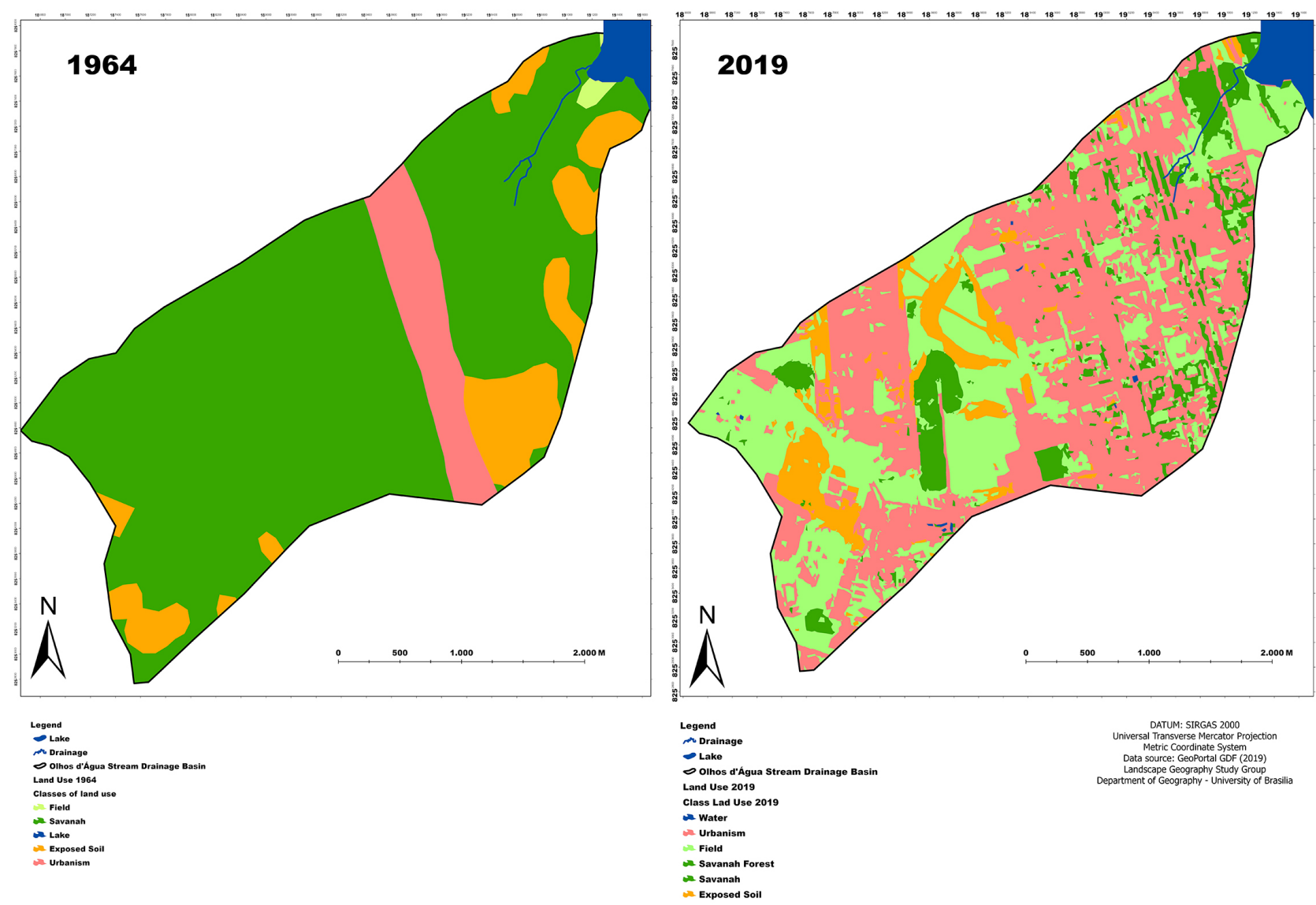

Figure 3. Land-use evolution of the drainage basin Olhos d água. 
This process of urban expansion was consolidated in the analyzed timescale. However, due to the urban expansion caused by the construction of a new neighborhood, called Northwest, the floods in Asa Norte tend to be more frequent and dangerous. The Northwest neighborhood is designated for a residential area and is located at the head of the drainage basin upstream of Olhos d' Água.

\subsection{Drainage Basin of Águas Claras}

The second drainage basin analyzed, is in a slightly different context from the previous area. It is an area outside the original planning pattern of the city of the Pilot Plan of Brasília. The drainage basin of Aguas Claras went through a very different process, being one of the most intense vectors of the real estate market, especially since 1999.

The processes of land-use change in the Aguas Claras basin have worsened due to the fact that the guidelines of the urban plan were more permissive, which favored the process of urban density. In this drainage basin, unlike the previous one, the presence of an intermittent drainage channel at the bottom of the valley, led to the delimitation of an ecological park to protect the area closest to the mouth of the stream. However, the headwaters areas, which had ephemeral behavior of surface drainage, were suppressed and urbanization was consolidated on these areas. Figure 4 shows the changes that occurred in the analyzed period. It is easy to observe the suppression of the stream areas, as well as the significant advance of the urban area with all its components.

This whole process of changes in land-use in the drainage basin is shown in Table 2. This table shows the alarming values that have been changed, in which the increase of urban areas is more than ten thousand percent increase from a mere 2,9 hectares to more than 313 hectares. In this same aspect, the characteristic vegetation of the region, savannah, has been suppressed by more than $90 \%$.

This equation is the disastrous verve of urban settlement models that do not take into account the systems operating in the drainage basins. This is the principal cause of frequent problems of flooding, as well as damage to the eco-hydrological system, especially in first-order channels, which are known to be the most sensitive.

One of the aspects that can be used to measure the damage caused by changes in types of land-use, is the process of exporting polluting cargo generated according to each class of land use in a given drainage basin. These studies can be applied to any drainage basin and different scales (Steinke \& Saito, 2008; Steinke et al., 2012; Steinke \& Saito, 2013). Therefore, for the purpose of estimated measurement, the polluting load estimation model for Sediments in Suspension (Ss) was used, in which each type of use has an estimated load generation value in $\mathrm{kg} / \mathrm{km}^{2} /$ day.

Impermeabilization increases sediment transportation in channels and decreases drainage density to carry the increased sediment load. Such conditions in 
urban environments can facilitate the accumulation of stormwater downstream more quickly than in natural river systems and produce high flood peaks. Frequent flooding damages buildings, gardens and it can disrupt traffic. The excess of storm runoff on saturated or paved soils cannot be used to recharge the groundwater baseflow during the dry season. The best solution to the urban runoff problem is to detain the stormwater in small volumes as near to its source as possible, and then to release it slowly to natural stream channels or to the groundwater system (Dunne \& Leopold, 1996).

Table 2. Land-use evolution of the drainage basin Aguas Claras.

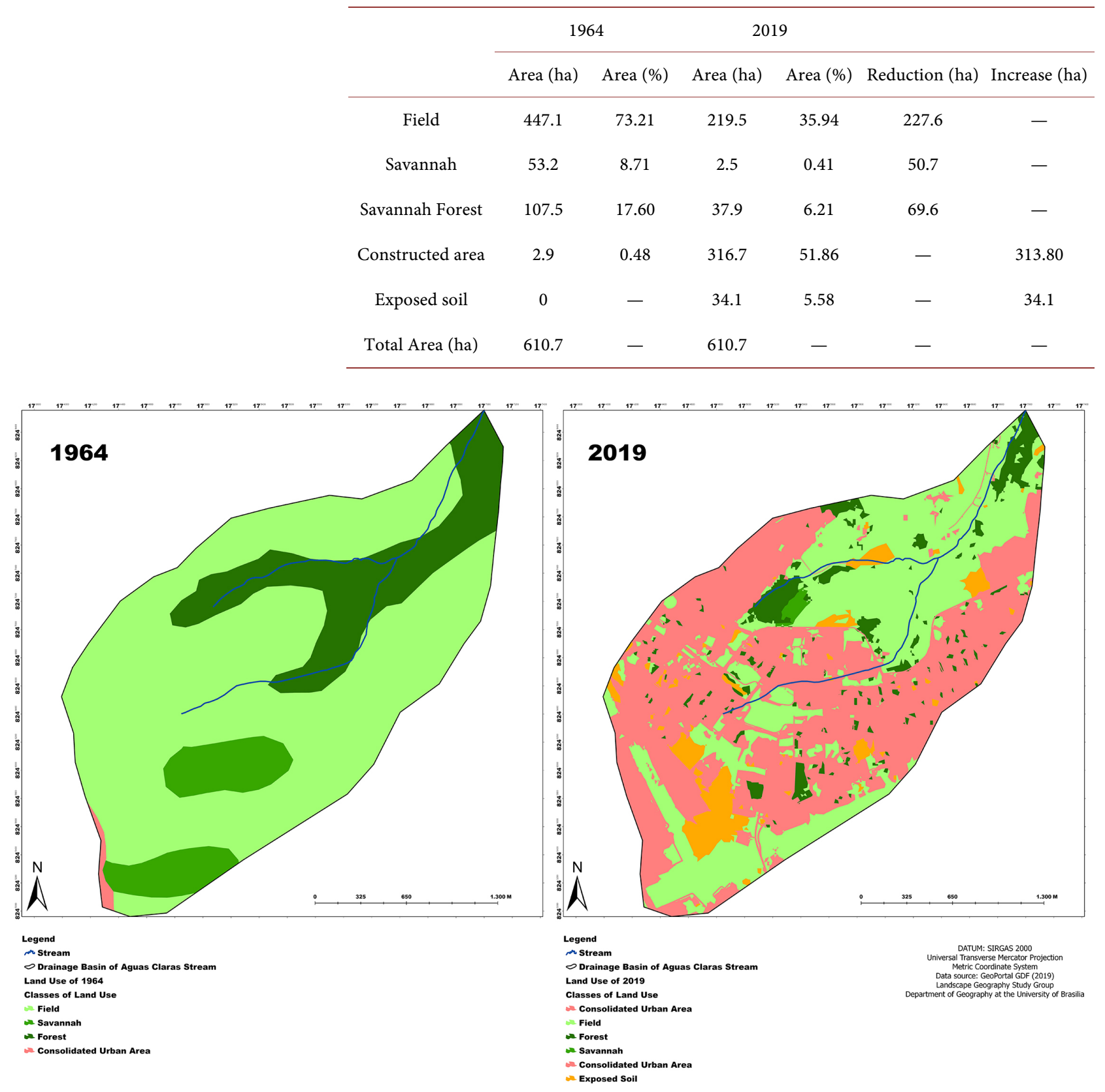

Figure 4. Land-use evolution of the drainage basin Aguas Claras. 
Figure 5 shows the behavior of the loads in the two basins and their respective values for 1964 and 2019. It is evident that the change to urban use, due to the loss of vegetation, results in a significant increase in these values. As a consequence, there is a silting process of the linked water systems, so the channels of immediately greater order and even the Paranoá Lake suffers from the silting processes. These silting processes of the Lake were reported by Franz et al. (2014).

To finalize the results and, in an attempt to seek an understanding of the complexity of the drainage basin occupation processes, a population density map was inserted (Figure 6). The insertion of this map has the expectation of glimpsing the other elements that generate changes in the drainage systems, such as the flow of automobiles, generation of solid and organic residues, among others.

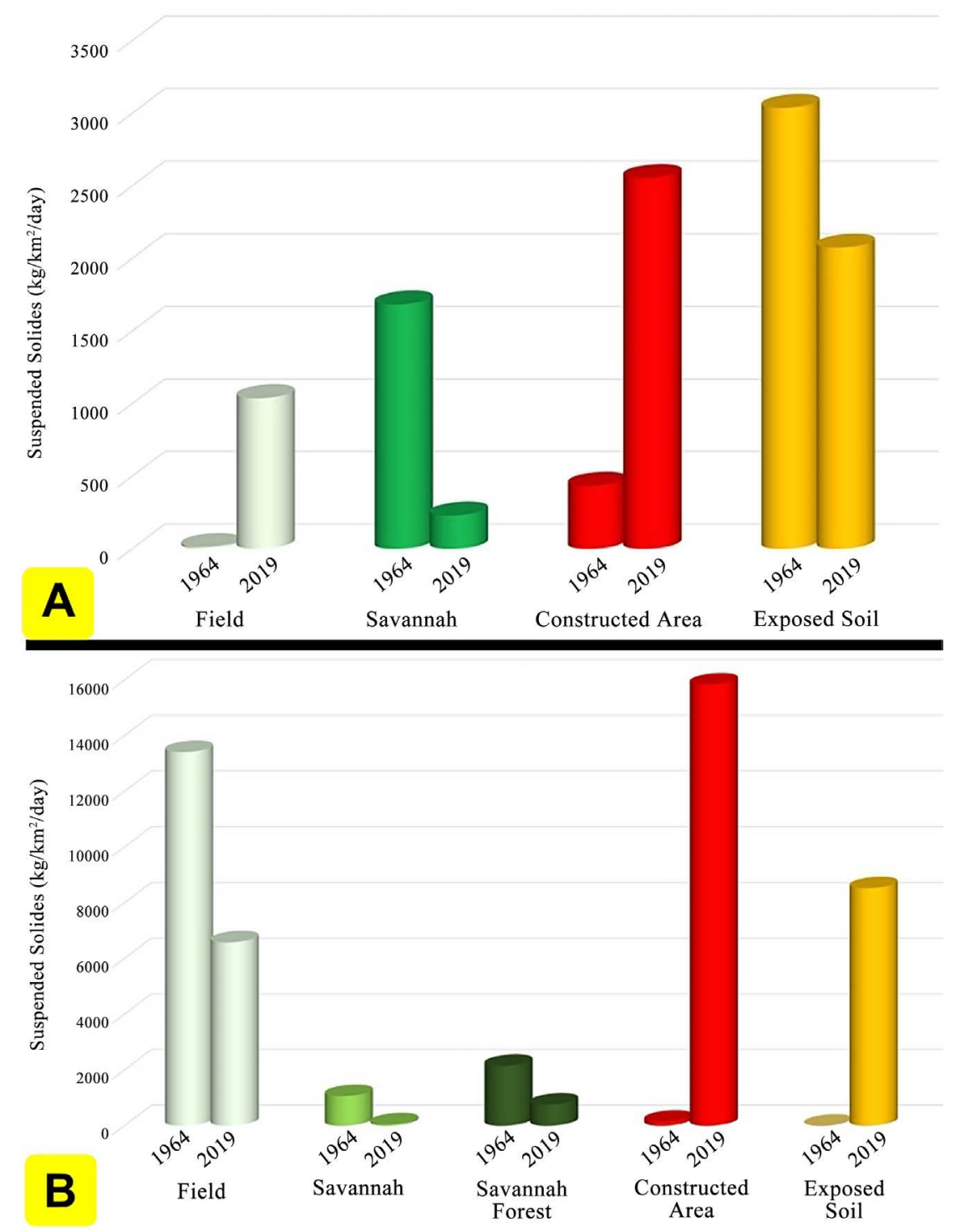

Figure 5. Pollution load export. (A) Drainage Basin of the Olhos D' Agua and (B) Drainage Basin of the Aguas Claras. 

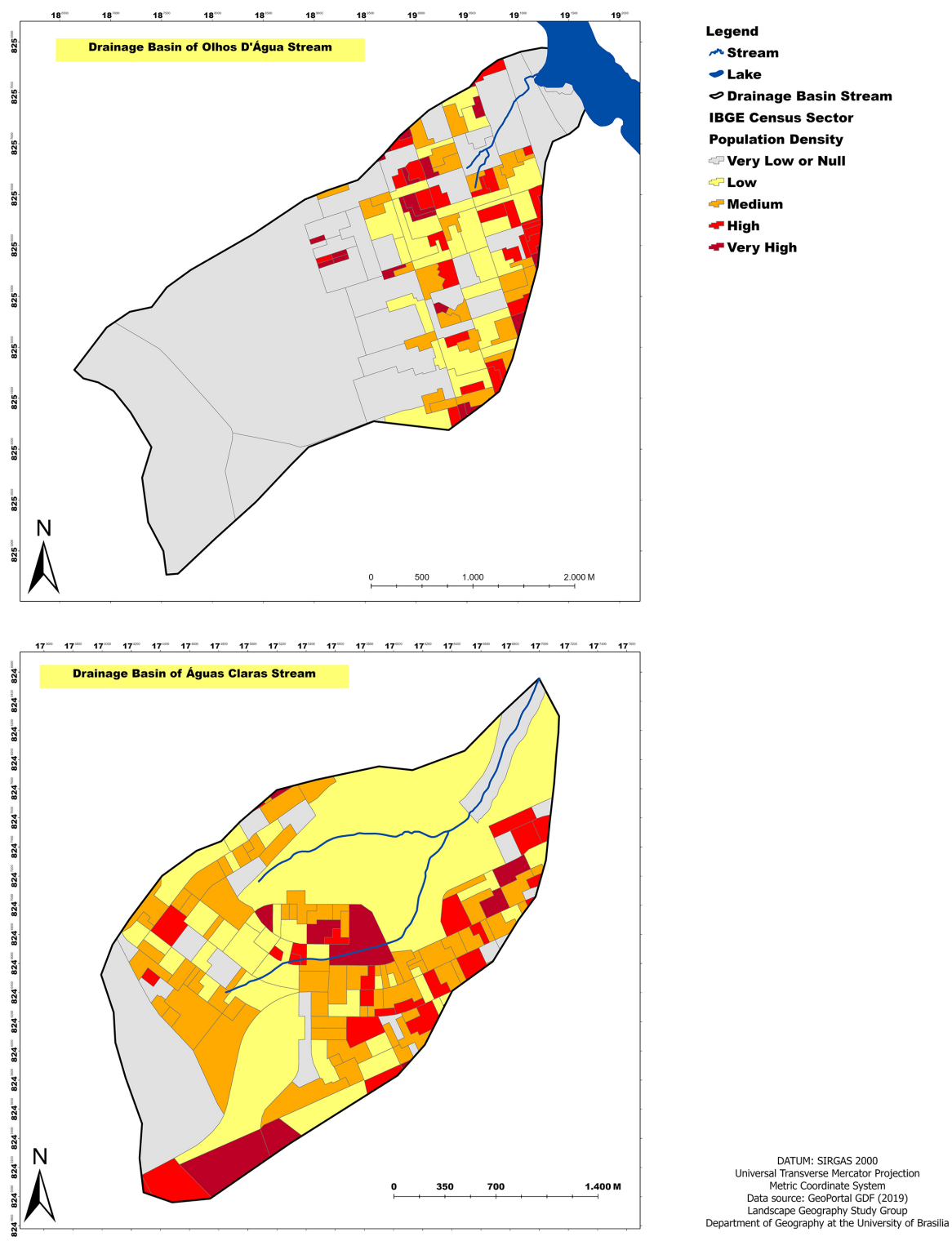

Figure 6. Population density.

The drainage basin of Aguas Claras presents a higher population density than the Pilot Plan of Brasília. This fact can be explained since the norms of urban use for this region were softer, which favored the construction of a larger number of buildings, with more housing units. In the drainage basin of Olhos D'Agua, the limits imposed by the original model and consolidated by the UNESCO tipping rules, resulting in a less intense population density process, but not without problems as already stated.

\section{Final Considerations}

The main reason by which the Pilot Plan of Brasília and Aguas Claras still suffers from recurrent floods in buildings and, mostly, in the "little axis", is due to the lack of look to the landscape, to the land. Even though Lúcio Costa had pointed 
out the importance of the rainwater runoff and the importance of the local topography, nowadays a UNESCO-listed World Heritage Site, this does not occur in practice. The construction of the modern city did not accomplish all plans of Lúcio Costa, it only had a superficial look at the topography and at the rainwater runoff. Besides that, the management of the city did not do anything to change the situation, risking the lives of numerous workers and residents of Asa Norte and harming many people during the wet season. It affects the social, economic, and cultural aspects of the city.

Moreover, the lack of data and information on the part of the governmental organs is equally unacceptable and worrying. The lack or difficulty to access the information hurts the Brazilian Constitution and prejudices Brazilian research and studies that can point out the problems in Brasília and present, in equal measure, solutions. Those researches are vital to the maintenance and preservation of the World Heritage Site of Brasília. Brasília can deteriorate itself due to its floods and due to the fact, the necessary interventions are not done.

The present study is a never done before research based on the Federal District and it brings results never seen before when analyzing the drainage basins located in urban spaces. We believe that this discussion could help urban planning and our scarce water resources. In future research, it could be useful to explore the relationship between the urban sprawl of the city and the number of floods that reach it every year, projecting scenarios and models which will be useful to comprehend and analyze the urban drainage basins.

It is worrying that 60 years after its construction, this world heritage site still has basic infrastructural problems. Even more worrying is the fact that the same problem happened in Aguas Claras with different factors. The main problem observed by this research is that, even though the Pilot Plan was planned and became one of the greatest modern architecture centers in the world, it still suffers a lot from flooding, especially in Asa Norte, the north side of the wings of the "airplane".

This study can be seen as a first stage of studies that the city of Brasilia demands, although the study is limited to just two drainage basins, located in original models distinct from urban planning, the study points out very strongly to the need more advanced and detailed studies on the drainage basins that are under pressure from the urban expansion process.

\section{Acknowledgements}

The authors would like to thank the Laboratory of Multimedia Geoiconography LAGIM and the Landscape Geography Study Group, both linked to the Department of Geography at the University of Brasília.

\section{Conflicts of Interest}

The authors declare no conflicts of interest regarding the publication of this paper. 


\section{References}

Abrams, M., \& Prescott, C. (1999). The Endangered Species Act Enters the Urban Landscape: Can Portland Streams Sustain Salmon? In R. Sakrison, \& P. Sturtevant (Eds.), Watershed Management to Protect Declining Species (pp. 95-98). Seattle, WA: American Water Resources Association.

Adler, R. F. (2010). Evaluation of a Satellite-Based Global Flood Monitoring System. International Journal of Remote Sensing, 31, 3763-3782.

https://doi.org/10.1080/01431161.2010.483489

Anjos, R. S. A. dos, Vilela, R. de O. V., Santos, A. C. B., \& Oliveira, J. (2015). Brasilia-Monitoring and Trends of Urban Growth, Spatial Densities and Territorial Conflicts. 10th Space Syntax Symposium (SSS10), London, 23-24.

Booth, D. B., \& Henshaw, P. C. (2001). Rates of Channel Erosion in Small Urban Streams. In Land Use and Watersheds: Human Influence on Hydrology and Geomorphology in Urban and Forest Areas (pp. 17-38). Washington: American Geophysical Union.

Braga, R., \& Carvalho, P. F. (2004). Cidade: Espaço da cidadania. In A. B. R. Giometti, \& R. Braga (Eds.), Pedagogia Cidadã: Cadernos de Formação: Ensino de Geografia (pp. 105-120). São Paulo: UNESP-PROPP.

Campos, J. E. G. (2004). Hidrogeologia do Distrito Federal: Bases para a gestão dos recursos hídricos subterrâneos. Revista Brasileira de Geociências, São Paulo, 34, 41-48. https://doi.org/10.25249/0375-7536.20043414148

Cosac, D. C. S., \& Silvano, D. L. (2016). The Contribution of an Urban Park to the Conservation of Birds in Federal District, Brazil. Atualidades Ornitológicas, 193, 33-40.

Deckker, T. (2016). Brasília: Life beyond Utopia. Architectural Design, 86, 88-95. https://doi.org/10.1002/ad.2050

Dietrich, W. E., \& Dunne, T. (1993). The Channel Head. In K. Bcven, \& M. J. Kirkby (Eds.), Channel Network Hydrology (p. 330). Hoboken, NJ: John Wiley \& Sons Ltd.

Dunne, T., \& Leopold, B. L. (1978). Water in Environmental Planning. San Francisco, CA: W.H. Freeman.

Environmental Institute of Brasilia (2017). Estudo técnico: Criação do Parque Ecológico de Águas Claras (34 p.). (In Portuguese)

Francisco, R. A., Valentin, E. F. D., de Souza, N. M., \& Walde, D. H. (2006). Erosion Modeling in Hydrographic Pilot Basins in Brasília (Federal District), Brazil. London: The Geological Society of London, Paper Number 427.

Franz, C., Makeschin, F., Weiß, H., \& Lorz, C. (2014). Sediments in Urban River Basins: Identification of Sediment Sources within the Lago Paranoá Catchment, Brasilia DF, Brazil-Using the Fingerprint Approach. Science of the Total Environment, 466-467, 513-523. https://doi.org/10.1016/j.scitotenv.2013.07.056

Garcia-Pintado, J. et al. (2015). Satellite-Supported Food Forecasting in River Networks: A Real Case Study. Journal of Hydrology, 523, 706-724. https://doi.org/10.1016/j.jhydrol.2015.01.084

Gonçalves, T. D., Lohe, C., \& Campos, J. E. G. (2015). Hydraulic Characterization from Porous Aquifers of the Brazilian Federal District. Brazilian Journal of Geology, 45, 259-271. https://doi.org/10.1590/23174889201500020006

Hollis, G. E. (1975). The Effect of Urbanization on Floods of Different Recurrence Interval. Water Resources Research, 11, 431-435. https://doi.org/10.1029/WR011i003p00431

$\mathrm{Hu}, \mathrm{M}$. et al. (2017). Evaluation of Low Impact Development Approach for Mitigating Food Inundation at a Watershed Scale in China. Journal of Environmental Manage- 
ment, 193, 430-438. https://doi.org/10.1016/j.jenvman.2017.02.020

Kennedy, K. (1999). What's So Special about the Edwards Aquifer? In R. Sakrison, \& P. Sturtevant (Eds.), Watershed Management to Protect Declining Species (pp. 115-118). Seattle, WA: American Water Resources Association.

Konrad, C. P., \& Booth, D. B. (2002). Hydrologic Trends Associated with Urban Development in Western Washington Streams US (40 p.). Geological Survey Water Resources Investigations Report 02-4040.

Leopold, L. B., Wolman, M. G., \& Miller, J. P. (1964). Fluvial Processes in Geomorpholo$g y(504$ p.). San Francisco, CA: W.H. Freeman.

Lin, Y.-P., Hong, N.-M., Wu, P.-J., Wu, C.-F., \& Verburg, P. H. (2007). Impacts of Land Use Change Scenarios on Hydrology and Land Use Patterns in the Wu-Tu Watershed in Northern Taiwan. Landscape and Urban Planning, 80, 111-126. https://doi.org/10.1016/j.landurbplan.2006.06.007

Melo, L. A. M. P., \& Steinke, V. A. (2013). Avaliação da dinâmica de urbanização no Distrito Federal entre 2005 e 2009. Geografia (Rio Claro. Impresso), 38, 491-509.

Mishra, B. K. et al. (2017). Assessment of Future Food Inundations under Climate and Land Use Change Scenarios in the Ciliwung River Basin, Jakarta. Journal of Flood Risk Management, 11, S1105-S1115. https://doi.org/10.1111/jfr3.12311

Missouri Botanical Garden (2002). What Is a Watershed? Missouri Botanical Garden. http://www.mbgnet.net/fresh/rivers/shed.htm

Nelson, E. (1999). Sediment Budget of a Mixed-Use, Urbanizing Watershed. In R. Sakrison, \& P. Sturtevant (Eds.), Watershed Management to Protect Declining Species (pp. 469-472). Seattle, WA: American Water Resources Association.

Papa, F., Prigent, C., \& Rossow, W. B. (2007). Ob’ River Food Inundations from Satellite Observations: A Relationship with Winter Snow Parameters and River Runoff. Journal of Geophysical Research Atmospheres, 112, D18103. https://doi.org/10.1029/2007JD008451

Regional Administration of Águas Claras (2020). Meet the AR. (In Portuguese). Regional Administration of ÁguasClaras.

Rhoades, C. C., Entwistle, D., \& Butler, D. (2011). The Influence of Wildfire Extent and Severity on Streamwater Chemistry, Sediment and Temperature Following the Hayman Fire, Colorado. International Journal of Wildland Fire, 20, 430-442. https://doi.org/10.1071/WF09086

Risi, R. D. et al. (2013). Flood Risk Assessment for Informal Settlements. Natural Hazards, 69, 1003-1032. https://doi.org/10.1007/s11069-013-0749-0

Rogers, G. O., \& DeFee II, B. B. (2005). Long-Term Impact of Development on a Watershed: Early Indicators of Future Problems. Landscape and Urban Planning, 73, 215-233. https://doi.org/10.1016/j.landurbplan.2004.11.007

Salles, P., Bredeweg, B., \& Caldas, A. L. R. (2008). A Qualitative Model on Sustainability of the Riacho Fundo Basin (Brasília, Brazil). International Congress on Environmental Modelling and Software, Barcelona, 124.

https://scholarsarchive.byu.edu/iemssconference/2008/all/124

Sayama, T., Tatebe, Y., \& Tanaka, S. (2015). An Emergency Response-Type Rainfall-Runoff-Inundation Simulation for 2011 Thailand Foods. Journal of Flood Risk Management, 69, 65-78.

Schueler, T. (2000). The Importance of Imperviousness: The Practice of Watershed Protection (pp. 7-18). Ellicott City, MD: Center for Watershed Protection.

Steiner, F., Blair, J., McSherry, L., Guhathakurta, S., Marruffo, J., \& Holm, M. (2000). A 
Watershed at a Watershed: The Potential for Environmentally Sensitive Area Protection in the Upper San Pedro Drainage Basin (Mexico and USA). Landscape and Urban Planning, 49, 129-148. https://doi.org/10.1016/S0169-2046(00)00062-1

Steinke, V. A., \& Saito, C. H. (2008). Exportação de carga poluidora para identificação de áreas úmidas sob risco ambiental na bacia hidrográfica da lagoa Mirim. Sociedade \& Natureza (UFU. Impresso), 20, 43-67. https://doi.org/10.1590/S1982-45132008000200003

Steinke, V. A., \& Saito, C. H. (2013). Priority Wetlands for Conservation of Waterbird's Diversity in the Mirim Lagoon Catchment Area (Brazil-Uruguay). Pan-American Journal of Aquatic Sciences, 8, 221-239.

Steinke, V. A., \& Sano, E. E. (2011). Semi-Automatic Identification, GIS-Based Morphometry of Geomorphic Features of Federal District of Brazil. Revista Brasileira de Geomorfologia, 12, 3-9. https://doi.org/10.20502/rbg.v12i1.213

Steinke, V. A., Ferreira, L., \& Saito, C. H. (2012). Modelagem de exportação de carga poluidora na bacia hidrográfica do rio Jaguarão (fronteira Brasil Uruguai): Um refinamento em nível hierárquico inferior na modelagem desenvolvida para a bacia da lagoa Mirim. Geografia (Rio Claro. Impresso), 37, 127-146.

Tenorio, G. S., \& dos Santos Júnior, R. G. (2010). Setor Noroeste, Brasilia: Can an Elite Neighborhood Be Considered Green? 46th ISOCARP Congress 2010, Nairobi, Kenya, 19-23 September 2010, 1-13.

Thornton, M. T. (2005). Environmental Injustice in Brasilia: Who Are the People Living in Estrutural and Why (151 p.)? Latin America Studies.

U.S. Forest Service (2019). What Is a Watershed? Rocky Mountain Research Station-Air, Water and Aquatic Environments Sciences Program.

https://www.fs.fed.us/rm/boise/research/techtrans/projects/scienceforkids/watersheds.s $\underline{\mathrm{html}}$

U.S. Geological Survey (n.d.). Watersheds and Drainage Basins. United States Geological Service.

https://www.usgs.gov/special-topic/water-science-school/science/watersheds-and-drai nage-basins?qt-science center objects $=0 \#$ qt-science center objects

U.S. National Ocean Service (NOAA). (2020). What Is a Watershed? National Ocean Service Website. https://oceanservice.noaa.gov/facts/watershed.html

Wardah, T., Bakar, S. H. A., Bardossy, A., \& Maznorizan, M. (2008). Use of Geostationary Meteorological Satellite Images in Convective Rain Estimation for Flash-Food Forecasting. Journal of Hydrology, 356, 283-298.

https://doi.org/10.1016/j.jhydrol.2008.04.015

White, M. D., \& Greer, K. A. (2006). The Effects of Watershed Urbanization on the Stream Hydrology and Riparian Vegetation of Los Peñasquitos Creek, California. Landscape and Urban Planning, 74, 125-138. https://doi.org/10.1016/j.landurbplan.2004.11.015

Williams, D. (1999). Sustainable Urban and Regional Design: The South Dade Watershed Project. In R. Sakrison, \& P. Sturtevant (Eds.), Watershed Management to Protect Declining Species (pp. 457-460). Seattle, WA: American Water Resources Association. 